\title{
Translators' Perspectives: The construction of the Peruvian Indigenous Languages Act in indigenous languages
}

\author{
RAQUEL DE PEDRO RICOY \\ Heriot-Watt University, Edinburgh, UK \\ r.de_pedro@hw.ac.uk \\ ROSALEEN HOWARD \\ Newcastle University, Newcastle-upon-Tyne, UK \\ r.e.howard@newcastle.ac.uk \\ LUIS ANDRADE CIUDAD \\ Pontificia Universidad Católica del Perú, Lima, Perú \\ lfandrad@pucp.edu.pe
}

\begin{abstract}
RESUMEN
En la Latinoamérica contemporánea está emergiendo la necesidad apremiante de traducir los textos jurídicos de las lenguas de las antiguas potencias coloniales europeas a las muchas lenguas indígenas que se hablan en la región. En el presente artículo, abordamos este asunto en el contexto de la promulgación de leyes que dictan a los Estados el deber de defender los derechos humanos lingüísticos. Tomamos como estudio de caso la traducción de la Ley de Lenguas Indígenas peruana (2011) del español a cinco idiomas amerindios, una iniciativa que podría considerarse como una práctica poscolonial situada en la interfaz comunicativa entre el Estado y los pueblos indígenas del Perú. Nos centramos específicamente en el comportamiento estratégico de los traductores indígenas, tal como lo describen ellos mismos, al comunicar a sus pueblos la norma estatal contenida en la legislación. Para estudiar este comportamiento no aplicamos un modelo de análisis textual, sino que adoptamos un enfoque basado en las percepciones que tienen los traductores de su rol y en su motivación para adoptar determinadas estrategias de traducción. Nuestro análisis combina aspectos teóricos de los estudios de traducción, estudios jurídicos y estudios poscoloniales para explorar de forma crítica la traducción del discurso jurídico en español a las lenguas indígenas del Perú, llevada a cabo, crucialmente, por traductores bilingües que se posicionan desde su "interior cultural".
\end{abstract}

\section{RÉSUMÉ}

En l'Amérique latine contemporaine, le besoin de traduire les textes juridiques des langues des anciennes puissances coloniales européennes dans les nombreuses langues autochtones parlées dans la région est criant. Dans cet article, nous abordons les questions concernant cette initiative dans le cadre de l'obligation des États de faire respecter les droits humains linguistiques. Nous y étudions la traduction de la Loi péruvienne des langues (2011) de l'espagnol en cinq langues amérindiennes, qui sera considérée comme une pratique postcoloniale située à l'interface de la communication entre l'Etat et les populations autochtones du Pérou. Notre intérêt spécifique est le comportement stratégique des traducteurs autochtones, tel que décrit par eux-mêmes, lorsqu'ils communiquent à leurs peuples les normes de l'État contenues dans la loi. Afin d'étudier ce comportement, nous n'utilisons pas l'analyse textuelle, mais nous privilégions une approche basée sur les perceptions des traducteurs de leur rôle et de leurs motivations des stratégies de traduction qu'ils ont adoptées. Notre analyse combine des aspects théoriques des études de traduction, des études juridiques et des études postcoloniales pour examiner la traduction du discours juridique de l'espagnol dans les langues indigènes du Pérou, telle qu'elle est, de manière décisive, menée par des traducteurs bilingues situés «à l'intérieur » sur le plan culturel. 


\begin{abstract}
An urgent need is emerging in contemporary Latin America for the translation of legal texts from the languages of former European colonial powers into the many indigenous languages spoken across the region. This article addresses the issue in relation to the rise of legislation that requires States to uphold the principle of linguistic human rights. It takes as a case study the translation of the Peruvian Indigenous Languages Act (2011) from Spanish into five Amerindian languages, viewed as a postcolonial practice situated at the communicative interface between the State and the country's indigenous populations. Our specific interest is the strategic behavior of the indigenous translators, as described by themselves, when communicating to their peoples the State norms contained in the Indigenous Languages Act. In order to analyze this behavior, we depart from text-analytical models and favor an approach based on the translators' perceptions of their role and their rationales for the translation solutions adopted. The analysis combines theoretical strands from translation studies, legal studies and postcolonial studies so as to throw light on the translation of legal discourse from Spanish into the indigenous languages of Peru, as conducted, crucially, by bilingual translators situated on the cultural "inside".
\end{abstract}

\title{
PALABRAS CLAVE/MOTS-CLÉS/KEYWORDS
}

traducción jurídica, lenguas indígenas, Perú, derechos lingüísticos, poscolonialismo traduction juridique, langues autochtones, Pérou, droits linguistiques, postcolonialisme legal translation, indigenous languages, Peru, language rights, postcolonialism

\section{Introduction}

The Spanish conquest of the Americas, as was the case with the European imperialist enterprise worldwide, gave rise to extensive and persistent efforts to translate and interpret across the cultural and linguistic divides that opened up between native populations and colonial powers. In early periods, such efforts, aimed at communicating the values and principles of the colonizers to the native populations, focused particularly on translating Christian religious doctrine from Spanish into the Amerindian languages (Durston 2007, Hanks 2010). Today, while religious proselytism continues to provide the motivation for much translation practice, a new and urgent need is emerging for translation of legal texts into the many indigenous languages still spoken across the Latin American sub-continent.

Since the late twentieth century, post-colonialist approaches to the academic study of cultural production have informed the field of Translation Studies, especially as far as translation of literary texts is concerned. Our study will broaden the debate by focusing on the translation of a piece of legislation, namely Peru's most recent Indigenous Languages Act (Ley n. 29735), from Spanish into the wide range of Amerindian languages spoken across the Andes and Amazonia. Our specific object of study is the strategic behavior of the indigenous translators, as described by themselves, when communicating the State norms contained in the Indigenous Languages Act to their peoples. To this end, we depart from text-analytical models and favor an approach based on the translators' perceptions of their role and on their rationales for the translation solutions they chose. We seek to combine the tools of translation analysis with strands from legal studies and postcolonial studies in an innovative way, so as to throw light on the translation of legal discourse from Spanish into the indigenous languages of Peru, as conducted by bilingual speakers situated on the cultural "inside".

To meet this aim, we will first explore issues relevant to the translation of legislation and comment on the problems that arise from legal translation in a postcolonial, multicultural setting such as Peru. We will then provide an analysis of five translations of the Indigenous 
Languages Act based on retrospective Think Aloud Protocols (TAPs) conducted with the translators. Finally, we will discuss the findings derived from our analysis. In order to provide relevant context, we commence by outlining the background to the Indigenous Languages Act and the process whereby it came to be translated.

The Peruvian Indigenous Languages Act, as it is commonly known, passed in July 2011, has as its object "to regulate the use, preservation, development, recuperation, promotion and dissemination of the country's indigenous languages", as expressed in its long title in Spanish (Ley que regula el uso, preservación, desarrollo, recuperación, fomento y difusión de las lenguas originarias del Perú). ${ }^{2}$ Given its stated purpose, it was apt that, some three years after the passing of the Act, and as part of a range of actions taken to publicize the existence of the Act among the communities of speakers who constitute its intended beneficiaries, the Peruvian State, in the shape of the Ministry of Culture, commissioned its translation into a wide range of the languages. Unlike the source text, the target texts do not carry legislative weight and are not opposable to the Act in Spanish. Their value, rather, is communicative and symbolic. The texts were published, both in print form and orally recorded on $\mathrm{CD}$, and distributed in a series of public events across the country organized by the Ministry. ${ }^{3}$ As stated in the Presentation of the texts, their purpose is "to disseminate the contents of the Act, guarantee its implementation, and contribute to the positive recognition of linguistic and cultural diversity in [Peru]" (Ministerio de Cultura 2014: 3, our translation).

This ambitious initiative has to be considered against a highly complex sociolinguistic and cultural backdrop. As Translation Studies scholars concerned with the sociological siting of translation demonstrate, ${ }^{4}$ translation between any language pair is influenced by the relative social-cultural position that each language occupies. In the Peruvian context, the difficulty entailed by the genetic and typological divergences between Spanish and the estimated forty-seven Amerindian languages of Peru is compounded by the fact that the translation process is being conducted between languages whose historical interrelationship carries a burden of social inequality and injustice. Thus, it is reasonable to assume that the translators of the Indigenous Languages Act faced challenges that stemmed from such cultural and linguistic asymmetries.

Our analysis explores the perceptions of five of them (speakers of Ashaninka, Shipibo, Aymara, Chanka Quechua, and Ancash Quechua) as to these challenges and their descriptions of the strategies that they applied in order to negotiate the transfer of meaning. Before we present the findings derived from our analysis, we will contextualize the situation in Peru within relevant literature and explain the methodology that we adopted.

\section{Translating legal texts in postcolonial, multicultural settings}

The translation of legal texts, embedded as they are in specific traditions of Law, raises particular problems in multicultural settings. Šaršević (1997: 14) observes: "The difficulty of a legal translation depends primarily on the [degree of] affinity of the legal systems and only subsidiarily on the [degree of] affinity of the source and target languages". Although she appears to relativize the importance of structural differences between languages, it can be argued that these create serious difficulties when the source language has a long-written tradition and well-established legal text-generic and discursive patterns, whereas the target language does not. She uses Switzerland as an example of how "translation operations are greatly simplified" (Šaršević 1997: 15) once a nomenclature has been agreed upon. True 
though this may be, in the case of Peru, as in other postcolonial contexts, a conceptual asymmetry between the source and target cultures (Spanish-speaking and indigenous, respectively) has to be added to the absence of equivalents in the indigenous languages for the specialized lexicon in the hegemonic language: there is effectively a non-equivalence of systems.

In his epistemic approach to the comparison of common law and civil law in the European context, Legrand (1996) remarks on the crucial role that "legal mentality" plays in the understanding of the law, thereby highlighting the difficulties that stem from the conceptual asymmetry mentioned above:

\begin{abstract}
The essential key for an appreciation of a legal culture lies in an unravelling of the cognitive structure that characterises that culture. The aim must be to try to define the frame of perception and understanding of a legal community so as to explicate how a community thinks about the law and why it thinks about the law in the way it does. (Legrand 1996:60)
\end{abstract}

Glanert (2014: 22) elaborates further on the issue: "Within 'comparative law and comparative legal studies' it appears that one must admit that certain deep structures are untranslatable, while significant partial understanding is preferable to no understanding at all." That is, although the language of the law can be translated, the cognitive structures that it embodies, upon which understanding hinges, may not be. This is relevant to the translation of the Peruvian Indigenous Languages Act (a civil-law normative) into the languages of the Amerindian peoples, whose legal culture is rooted in customary law and, therefore, underpinned by different cognitive structures. Additionally, by creating a communicative interface that will enable the native peoples to reach an understanding, however partial, of the principles enshrined in the Act (which directly concern their linguistic rights), is, arguably, an effective way to raise or increase awareness of their entitlements among them.

In relation to the need to translate legislation, Cao (2007: 101) identifies two types of situation in which this is the case: the first one, "in bilingual or multilingual jurisdictions where two or more languages are the official legal languages", and the second, "in any monolingual country where its laws are translated into a foreign language or languages for information purposes". ${ }^{5}$ In the first case, the purpose of translation is normative, "to publish the law in the language or languages of the citizens so that the law can be enforced" (Cao 2007: 103). In the second case, "translations are used for informative rather than normative purpose. The translated text does not have any legal force, and the original law and the translated text are not equal" (Cao 2007: 103).

Neither of these types of situation quite coincides with that of Peru. In this case, firstly, we have a multilingual jurisdiction where all languages are de jure official "in the zones where they predominate", as expressed in the Indigenous Languages Act. Furthermore, the cases of jurisdictions such as Canada, Switzerland and Hong Kong, which Cao (2007: 101) uses as examples, presume that the different language versions of the statutes are equally authentic and opposable, which is not the case in Peru: as mentioned above, while the status of the Peruvian Indigenous Languages Act in Spanish is one of legislative power, its translations do not have equivalent status, not having undergone the required authentication process for this to be the case. Cao (2007: 10; citing Šaršević 1997 and Correia 2003) describes such a process as one by virtue of which the target texts "are not mere translations of law, but the law itself'. ${ }^{6}$ Thus, the translations of the Indigenous Languages Act into the indigenous languages of Peru would not be, in functionalist terms, "instrumental" (Nord 2005), as their purpose, or Skopos, is not the same as that of the source text.

It could be argued that the situation in Peru corresponds more closely to the second scenario described by Cao. Insofar as the translations of the Indigenous Languages Act do not 
have the legal status of the source text, there is a function shift which renders an illocutionary act as a locutionary act (Austin 1962): a shift from enacting law to communicating information. However, since Peru is a constitutionally embodied multilingual state and the indigenous languages are deemed official, albeit in a circumscribed way, an analogy with such a scenario, where the law is being translated into a "foreign" language for informative purposes, would be paradoxical.

Given that the paradox just mentioned stems from the status of Peru as a postcolonial country, ${ }^{7}$ the intricacies of legal translation need to be considered, for the purpose of the present study, in the context of postcolonial theories of translation. Ever since (and including) Niranjana's seminal work Siting Translation was published in 1992, such theories, rooted in social anthropology, have often materialized in critiques that consider the tension that results from the power asymmetry between the colonizer and the colonized, and put forth suggestions as to how to counter the hegemonic ambitions of the former. In the post-colonialist literature, when texts are used to illustrate the violence that translation exerts on the cultures of the indigenous populations of former colonies, they tend to be literary or religious. Many of the studies relate to the colonization periods relevant in each case or the aftermath thereof, thereby providing historical perspectives and insights. The collections of essays edited by Bassnett and Trivedi (1999) and by Hermans (2006, 2014) on the subject of translation in postcolonial contexts bear witness to these trends.

Our study departs from such trends in a number of ways: firstly, it adopts an empirical approach; secondly, it neither draws evidence from nor theorizes on the translation of literary or religious texts; and thirdly, it focuses on a contemporary dataset. Nonetheless, some of the notions proposed by scholars operating within a post-colonialist (and, more often than not, post-structuralist) framework, namely, interventionism and subversion, are relevant in the context at hand.

Niranjana (1992: 173) claims that interventionist strategies, which are tantamount to a translation of resistance, can counter the colonial discourse. She was referring to translations of an Indian poem into English (the language of the Empire), but, as our analysis will show, intervention can also work in the opposite direction (from a majority, "world" language, into indigenous, minority, languages) and with respect to instantiations of non-literary genres (in our study, legal texts). Admittedly, this is, by necessity, a different kind of interventionism: one that appropriates the language of the hegemonic discourse, either by trying to replicate it in a lower-status language or by making it relevant to the shared knowledge and conventions of the target audience. The latter strategy is illustrated, for example, by the translation of the Universal Declaration of Human Rights from Spanish into Tzeltal, a Maya language spoken in Chiapas, Mexico, by couching it in a local genre called mantalil, a set of advice and principles used for guiding human behavior progressively, from childhood to adulthood (Pitarch 2001; Howard et al. forthcoming).

The above relates to another, much-used, concept in postcolonial theory: subversion. The tenets that are put forth in relevant literature typically relate to translation from the languages of the colonized to those of their colonizers. Spivak (2012 [1993]), for instance, highlights what she calls the immorality of less-powerful socio-cultural identities being eradicated in translation. Bhabha (1994), on the other hand, argues from a theoretical point of view that the cultural hybridity that evolves from the complex relationships of contact between the colonizers and the colonized can afford the latter the opportunity to subvert the discourse of the powerful. 
Bhabha's stance on the affordances of hybridity, questioned though it has been, is relevant to our study in that it is applicable to translation from the languages of the historical metropoles into the indigenous languages of the colonized territories, such as India, the Americas, Africa and Australia. However (and, perhaps, paradoxically), Rao's (2006: 89-91) critique from the perspective of a non-colonial (rather than post-colonial) translation, which, in his words, is "a radically foreign performance" and, therefore, "is not a mere 'rearticulation', 'revaluation', 'reversal', or 're-enunciation' of the original” (Rao 2006: 90) is also relevant. He claims that "the original [is] a radical immanence indifferent to the (colonial) world and therefore untranslatable into it" (Rao 2006: 89). In other words: the source text is inherent to the political and cultural systems that rule (post-) colonial societies, but it is alien to their indigenous populations, which makes translation into their languages a futile endeavor, if not an impossibility.

The notion of untranslatability is, of course, contingent on how "translation" is defined or understood; yet the data analysis that follows leads us to suggest that the respondents found themselves as "foreign performers" of a text that was both "immanent" by dint of its very nature (being as it is part of the Peruvian State's legislation) and "indifferent" to the conceptualization of laws and regulations by their indigenous linguistic communities.

The abovementioned debates have to be contextualized within the notion of "committed translation", a term used by Simon (1996) in relation to feminism that has become associated with practices that visibilize collectivities that are oppressed or discriminated against. The methodology that we chose for eliciting data (see the following section) regarding strategic behavior allows us to ascertain whether the decisions that each translator made in order to relay the Indigenous Languages Act into the indigenous languages covered in this paper were either the result of a deliberate act of subversion of the discourse and genre patterns of the source text, as well as of the conventions of the dominant language (Spanish), or the result of idiosyncratic (Toury 1995) decisions to communicate a piece of the State's legislation to people who are on the periphery of decision-making processes, in terms to which they could relate.

\section{Research methodology}

We approach the study of the translations of the Peruvian Indigenous Languages Act via retrospective Think Aloud Protocols (TAPs) with the translators and/or reviewers of the translations into the following: two varieties of Quechua (Chanka as spoken in the department of Ayacucho and neighboring departments, and Ancash as spoken in the department of Ancash); Aymara as spoken in the southern highland department of Puno; Shipibo as spoken in the Amazonian department of Ucayali; and Ashaninka as spoken in the Amazonian region of the department of Junín. All the respondents combine their activities in the field of translation with other professional activities: the Chanka Quechua speaker is a civil servant who works at the Ministry of Culture; the Ancash Quechua speaker is a TV presenter and a digital language activist; the Aymara speaker is a university lecturer specialized in linguistics; the Shipibo speaker is a nurse and a radio presenter; and the Ashaninka speaker is a cultural activist and commentator.

In conducting the TAPs, we invited translators to read aloud the source text, then to read the corresponding translation, proceeding Article by Article through the text of the Act. They were asked to comment on the difficulties they had encountered in the translation process, the solutions they came up with, and how they came by these solutions. The use of TAPs proved the best method to reveal the respondents' perceptions of the strategies that had been applied (the focus of this article) and to elicit reflection. Furthermore, they were a very useful tool in the case of translation into languages of which we had limited practical 
knowledge. ${ }^{8}$ However, while we sought to keep verbal prompts and reactions to a minimum as in conventional TAP procedures, this was an unfamiliar style of interaction for the speakers and we tended toward the more interactive style of TAP argued for by some scholars (van den Haak et al. 2003). Each TAP lasted an average of three hours and in two cases we had to reconvene with the translators, as one session was not sufficient to cover the full text. All of them were subsequently transcribed. In addition to the TAPs conducted with the translators/revisers, during a separate phase of the research we conducted interviews with them, as well as with end users, speakers and readers of the target languages in question, to see how effective and comprehensible the resulting translations were in their eyes. The results of this phase of research will be elaborated on in future publications.

\section{Translating Peru's Indigenous Languages Act in practice}

In this section we will provide an outline of the process followed for translating the Indigenous Languages Act from the point of commission. This is followed by an analysis of the translation strategies adopted, as described by the TAP respondents.

\subsection{Translators' working methods and the nature of the task}

The Ministry of Culture, through its Indigenous Languages Division, commissioned the translations of the Peruvian Indigenous Languages Act. ${ }^{9}$ The latter set a submission deadline of around a month from delivery of the source text to the translators. The translators had completed the basic three-week training program in translation and interpreting in indigenous languages coordinated by the Division (known as the Curso Básico). The translation into each language was led by one person and revised by another, who, according to the TAP respondents, often took an active role in the negotiation of meaning, thus acting as a second translator. The two parties were frequently based in different locations, in which case the discussions between them took place by mobile phone rather than face to face.

The Indigenous Languages Division provided a basic intra-lingual glossary of legal terminology and facilitated contact between the translators and legal and other experts, who assisted by explaining the technical content of the Act and clarifying linguistic matters. The Aymara and Chanka Quechua respondents explained how this process worked in the following terms:

\footnotetext{
I have not seen the word "aru" used in this sense in any other translation, but we discussed the issue with professor X. [...] In this case we had to consult the lawyer at the Ministry of Culture himself: what does it mean "direct and inverse translation that guarantee" ...? (Aymara TAP: 3 November 2014; translated by the authors) ${ }^{10}$

We have a translator who has quite a lot of experience when it comes to translating, reading and so on from a communicative approach, rather than one that seeks to relay exactly something like a calque of things, so we consulted him... (Chanka Quechua TAP: 17 November 2014; translated by the authors) ${ }^{11}$
}

For the recoding of the Spanish source text, and, in order to reach an agreement as to its expression in the target language, the translators often relied on the knowledge and the intuition of other native speakers of the relevant indigenous language. The words of the Shipibo respondent are illuminating in this respect: 
teachers. (...) We received various contributions to the translation, but in the end we were the ones to decide what to write. (Shipibo TAP: 10 December 2014; translated by the authors) $)^{12}$

A representative of the commissioning (Ministry of Culture) team informed us that, at the beginning of the translation process, a meeting was held with the translators to explain that the aim was not to produce a legally binding text, but rather to communicate the contents of the Act in the indigenous languages to their speakers, in order to spread understanding of their rights under the law (personal communication, email, September 2017). Nonetheless, as our TAP interviews suggest, there was some variation in practice as to how the translators interpreted the purpose of the task. The Ashaninka, Ancash Quechua, Chanka Quechua and Shipibo translators, in line with a communicative aim, simplified the expression and lowered the register. The Aymara reviser took a different approach, rising to what he saw as the challenge of reproducing the specialised register of the source text in the target text.

The latter aimed to maintain the "impersonality" and complexity ("obscurity") of the source text in the target language, as he explained:

[...] using legal language is difficult, isn't it? It is a different language, isn't it? So, whoever has to translate a legal text must have a good understanding of the Law, otherwise it will be fatal. Because that piece of legislation is going to be applied by a lawyer, isn't it? And, if the translator mistranslates an article, [translates it] in a different way, it is as if it had been underwritten by the President of the Republic, so that translation can prevail and he is ultimately not to blame, is he? And, perhaps, it could lead to an erroneous legal interpretation [thereof]. (Aymara TAP: 3 November 2014; translated by the authors) ${ }^{13}$

The other four respondents reworked the content to facilitate comprehension and so that the target audience could relate to it. In fact, the latter were often explicit that their aim was "to communicate the message", rather than reproduce the register of the source text. The Quechua Chanka translator elaborated on this point:

\footnotetext{
It has to be borne in mind that we were translating specifically for the [indigenous] speakers; therefore, it is a group who will not have been necessarily exposed to this type of document. Since they are not familiar [therewith], the aim was to communicate [the meaning], over and above retaining formal aspects. (Chanka Quechua TAP: 17 November 2014; translated by the authors) $)^{14}$
}

The Ashaninka, Ancash Quechua, Chanka Quechua and Shipibo translators chose to depart from the "direct and neutral" language of the Act and address their target audiences in terms more closely aligned with the communicative conventions of their peoples. This occasionally led, for example, to the use of first person plural pronouns to replace impersonal expressions. They thus effected a shift in the text-producer/text-receiver interaction: the State addressing its citizens in a detached, impersonal and general manner is replaced by the translator addressing his/her own people as a member of their linguistic and cultural community, as we will show below. Both approaches could be interpreted as "subversive", in that they entail an appropriation of an alien genre (one that is "immanent" to the source culture and "indifferent" to the target culture, to use Rao's terminology; see Section 2). This appropriation lies, in the case of the discursive strategy adopted by the Ashaninka, Ancash Quechua, Chanka Quechua and Shipibo respondents, in the intended effects of the abovementioned interaction shift and, in the case of the approach followed by the Aymara respondent, in the effort to introduce new text-generic patterns to the target language by reproducing the formal aspects of the source text.

\subsection{Translation strategies}


We shall now present the translation strategies that were adopted to negotiate the meaning transfer, as described by the TAP respondents. They also referred to morpho-syntactic modifications (word order, suffixation) that were determined by the rules of the target language. These have been excluded from our analysis, since they are obligatory shifts and, as such, not the result of strategic behavior, the description of which is the object of our study. We have taxonomized their strategies in the table below; however, it should be noted that the respondents themselves did not necessarily use the labels included in our classification.

TABLE 1

Strategies described by the translators

\begin{tabular}{|c|c|c|c|c|c|}
\hline & $\mathrm{ASH}$ & AY & AQ & CQ & $\mathrm{SH}$ \\
\hline Comments & & & $\sqrt{ }$ & & \\
\hline Rephonologisation & & $\sqrt{ }$ & & & \\
\hline Calque & & $\sqrt{ }$ & & & \\
\hline Dialectal variations & $\sqrt{ }$ & & $\sqrt{ }$ & & \\
\hline Definition & & $\sqrt{ }$ & $\sqrt{ }$ & $\sqrt{ }$ & $\sqrt{ }$ \\
\hline Rephrasing & $\sqrt{ }$ & $\sqrt{ }$ & $\sqrt{ }$ & $\sqrt{ }$ & $\sqrt{ }$ \\
\hline $\begin{array}{l}\text { Grammaticalisation: } \\
\text { Abstract noun(-phrase) }>\text { declarative sentence } \\
\text { Abstract adjective }>\text { declarative sentence } \\
\text { Noun phrase }>\text { interrogative sentence }\end{array}$ & & $\begin{array}{l}\sqrt{ } \\
\sqrt{ } \\
\sqrt{ }\end{array}$ & $\begin{array}{l}\sqrt{ } \\
\sqrt{ } \\
\sqrt{ }\end{array}$ & $\begin{array}{l}\sqrt{ } \\
\sqrt{ } \\
\sqrt{ }\end{array}$ & $\begin{array}{l}\sqrt{ } \\
\sqrt{ }\end{array}$ \\
\hline Borrowing (Spanish) & $\sqrt{ }$ & $\sqrt{ }$ & $\sqrt{ }$ & $\sqrt{ }$ & $\sqrt{ }$ \\
\hline Borrowing + definition & & $\sqrt{ }$ & $\sqrt{ }$ & $\sqrt{ }$ & \\
\hline Amplification & & $\sqrt{ }$ & $\sqrt{ }$ & $\sqrt{ }$ & \\
\hline Reduction & $\sqrt{ }$ & & & & $\sqrt{ }$ \\
\hline Specification & & & $\sqrt{ }$ & & \\
\hline Concentration (summary) & & & $\sqrt{ }$ & $\sqrt{ }$ & $\sqrt{ }$ \\
\hline Metonymy & $\sqrt{ }$ & $\sqrt{ }$ & $\sqrt{ }$ & $\sqrt{ }$ & $\sqrt{ }$ \\
\hline Archaism & & $\sqrt{ }$ & & & \\
\hline Hypernym & & $\sqrt{ }$ & & $\sqrt{ }$ & $\sqrt{ }$ \\
\hline Over-translation & & & & & $\sqrt{1}$ \\
\hline Omission & & & & $\sqrt{ }$ & $\sqrt{ }$ \\
\hline
\end{tabular}

Key: $\mathrm{ASH}=\mathrm{Ashaninka,} \mathrm{AY}=\mathrm{Aymara}, \mathrm{AQ}=$ Ancash Quechua, $\mathrm{CQ}=\mathrm{Chanka}$ Quechua, $\mathrm{SH}=\mathrm{Shipibo}$

As can be seen from the Table, the translators availed themselves of a range of strategies to overcome the challenges posed by the systemic and cultural asymmetries we mentioned above. Let us deal with each of them in turn.

Only the Ancash Quechua translator added COMMENTS in the form of annotations to justify lexical choices. These were rejected by the commissioners (probably because the strategy is at odds with the conventions of the legal genre), 
which led to some frustration on her part. She and the Ashaninka translator included DIALECTAL VARIATIONS to make their target texts more inclusive.

The Aymara respondent was the only one who explained that he had resorted to the use of ARCHAISM (thuxriña, a term coined in colonial times to denote an administrator, to translate instancia administrativa [Administrative body]), ${ }^{15}$ CALQUE (for interculturalidad [interculturality], combining the Aymara particle purapa [inter] and kultura [the Spanish word for "culture" transcribed in Aymara) and rephonologisation, i.e. an accommodation of the spelling of Spanish terms to the Aymara phonological system (e.g. Pirü for Perú) for terms proper to institutional and legal discourse (e.g. Congreso de la República [Congress of the Republic], Ministerio de Educación [Ministry of Education], Decreto Supremo [Presidential Decree]).

The Shipibo respondent pointed at OVER-TRANSLATION as a strategy that allowed him to relay his understanding of the text. For instance, he back-translated educación intercultural bilingüe (intercultural bilingual education) as en nuestro propio idioma, así como también se debe enseñar las tradiciones orales [in our own language, and also oral tradition must be taught].

SPECIFICATION was used by the Ancash Quechua respondent to translate medios de comunicación [communication (mass) media]: she specified the most frequently accessed media, as she questioned how many people would understand the collective term.

CONCENTRATION, or summary, was utilised by three of the respondents to bypass the conceptual entanglement of the text. The Ashaninka and Aymara respondents did not allude to the need for simplifying the long, convoluted sentences that are typical of legal language: the former described her experience of the task as largely unproblematic and the latter, as mentioned above, approached the task as a way of replicating an alien genre in his native language.

All the TAP respondents with the exception of the Ashaninka speaker indicated that they translated some terms by DEFINITION: toponimia [toponymy] (AQ, CQ, SH); traducción directa e inversa [direct and inverse translation] (AY, AQ); capítulo [part] (AQ, CQ); Constitución [Constitution] (AY); Registro Nacional de Lenguas Originarias [National Register of Indigenous Languages], lineamientos [ruling principles], normalización lingüística [language standardisation], cualitativos [qualitative] (SH); grupo etnolingüístico [ethnolinguistic group], individual [individual], colectivo [collective] (CQ); alfabeto [alphabet], investigación [research] (AQ). According to their explanations, whilst these terms are not part of the indigenous peoples' linguistic repertoires, they are part of their conceptual mappings.

GRAMMATICALISATION of noun and adjective syntagms was a common strategy, which appears to be a preferred optional shift determined by the communication patterns in the indigenous languages. Thus, an array of constructions which included abstract nouns (e.g. uso [use], discriminación [discrimination], derecho [right], extinción [extinction]) and adjectives (e.g. predominante [predominant], cualitativo [qualitative], cuantitativo [quantitative], arraigado [rooted]) were turned into declarative sentences. Similarly, abstract nominal and adjectival constructions were often turned into interrogative sentences. This was a strategy which was routinely applied, according to all respondents, to the rubrics of the Act: for instance, Definición de lenguas originarias (Definition of indigenous languages) would appear as "What are indigenous languages?" and Objeto de la Ley (Subject Matter of the Act) as "What is the Act for?"

AMPLIFICATION and REDUCTION were used to compensate for semantic asymmetries between languages. Interestingly, the respondents who are native speakers of Andean languages (AQ, CQ, AY) explained that they had to use a sequence of terms to relay the meaning of a Spanish word or combination of words (e.g. criterio [criterion], mantener y 
desarrollar [maintain and develop], dignidad cultural [cultural dignity]), whereas the two who are native speakers of an Amazonian language (ASH, SH) stated that, on occasion, a single word sufficed to cover the meaning of several Spanish ones: for instance, only one word was used to relay the meanings of planificado y progresivo (planned and progressive), pueblos originarios, andinos y amazónicos (indigenous peoples, Andean and Amazonian), and preservación y recuperación (preservation and recuperation).

The Shipibo translator explained that he also used OMISSION for, ostensibly, similar semantic reasons: entidades públicas y privadas (public and private bodies) became "public entities" in his version of the Act. He also deleted comunidades campesinas o nativas (peasant or native communities) altogether. The Chanka Quechua respondent resorted to the same strategy, but, in her case, to avoid redundancy: recuperación y preservación (recuperation and preservation) was translated simply as "preservation", as the idea of revitalizing the indigenous languages was included further on.

Three of the respondents used a HYPERNYM. The Aymara and Chanka Quechua speakers used it to translate Presidente (President), respectively, as "authority" and "head". The Shipibo speaker applied the strategy to Estado (State), which he relayed as apu, a term used by Andean highlanders to refer to the mountains as sacred beings, subsequently adopted by some Amazonian peoples to refer to the leaders of their political organizations.

All the respondents reported that they used rephrasing, borrowed terms from Spanish and metonymy:

REPHRASING was used when abstract terminology was used in the Spanish source text, such as mantenimiento y desarrollo (preservation and development), titularidad individual (individual entitlement), ejercicio de sus derechos (exercise of their rights), conocimientos tradicionales y la cosmovisión de los pueblos (ancestral knowledge and peoples' Weltanschauung), identidad (identity), and planificación (planning). The respondents' comments reveal that they resorted to paraphrases that were determined by their respective linguistic communities' cultural experience, sometimes using metaphors related to the natural world: e.g. lineamientos (ruling principles) as caminos que vas a abrir (paths that you are going to clear] in AQ; zonas de predominio (areas of predominance) as [lugares donde se ha] anidado ([places where one has] built a nest) and preservar (to preserve) as brotar (to sprout) in CQ.

BORROWING from Spanish was used across the board for what the translators described as "proper names", i.e. labels that are part of the institutional discourse or refer to State-led initiatives or categories (e.g. distrito, provincia o región [district, province or region], Patrimonio Cultural Inmaterial [intangible cultural heritage], ámbito público/privado [public/private sphere], política nacional [national policy]). It was also used for acronyms (e.g. CONCYTEC). Both the Aymara and Chanka Quechua respondents explained that on occasion they had used citative phrases that mean "the so-called" to bracket the borrowings. The fact that all respondents stated that "proper names" should not be translated, points at the instruction that they received as part of their training (the aforementioned Basic Course). That they interpreted this "rule of thumb" as being extendable to semantic fields that are alien to their peoples' sociocultural constructs was repeatedly attributed to their assumptions as to comprehensibility. The use of borrowing in the indigenous languages is widespread when there is no vocabulary to express exogenous concepts; if borrowings are well established, it is assumed that they will be generally 
understood. In other words, because most indigenous people will have come across the borrowed terms in Spanish through the media or other means, it was thought that it would be confusing if they were presented with translations for which no frame of reference exists.

Three of the respondents (all of them speakers of Andean languages: AY, AQ, CQ)

stated that, in some cases, they had added a definition to the Spanish terms: Mapa Etnolingüístico del Perú [Ethnolinguistic Map of Peru], (AQ, AY and CQ); Registro Nacional de Lenguas Originarias [National Register of Indigenous Languages] (AY); Patrimonio Cultural Inmaterial de la Nación [Intangible Cultural Heritage of the Nation] (CQ); Política Nacional [National Policy] (CQ); campaña [campaign] (CQ); normalización lingüística [language standardisation] (CQ), asistencia técnica [technical assistance] (CQ).

METONYMY was used to bring the institutional discourse closer to the target audience and their perceived understandings of western constructs. For instance, amazónico [Amazonian] was translated as de la selva [of the jungle] (AQ, CQ) or as gente de nuestro río, de nuestro bosque [people from our river, from our forest] $(\mathrm{SH})$; andino [Andean], as que vive en el cerro [who lives in the mountains] (SH) or del campo [from the countryside] (CQ); and de interés nacional [of national interest], as para el pueblo del Perú [for the Peruvian people] (AY).

Close analysis of the TAP responses shows that there were inconsistencies in the application of strategies within the same target text. It must also be noted that, according to the back-translations of the target text that the respondents sometimes provided, and the rationales they proffered, the choices that they made appear to have resulted in involuntary (non-strategic) semantic distortions and losses: for instance, afectan derechos [concern rights] became "damage rights" and sea factible [be feasible], "be better" in AQ; and cualitativos [qualitative] became "those who speak better" and en el territorio peruano [in Peru's territory], "when we live in a city" in SH.

However, it is the respondents' strategic behavior as explained by themselves (the object of study here) that is particularly revealing. The Aymara respondent is the outlier: he was the only one who understood the task that he was charged with as an opportunity to use translation as a way to develop a new genre in his language, rather than as a mere transmission of content. The other respondents appear to have seen their role as that of intermediaries between the State and their peoples, privileged communicators by dint of their comprehension of the source text and the structures it embodies, on the one hand, and of the sociocultural systems of their peoples, on the other.

In the cases of the Chanka Quechua and Shipibo translations, the TAP respondents commented that a further criterion guiding their choice of lexicon in translation was whether or not it was likely to be understood by the younger generation. There was a tendency to avoid words that remained in currency among older people but had fallen into disuse among the young. The Shipibo translator, experienced in working in media, had a strong view in this respect:

\footnotetext{
Because old people use very old terms that are no longer part of our everyday speech, especially that of the youth. Old people can use the terms among themselves, but young people don't speak like that anymore and however correct it may be, we have left that language behind and we choose not to use it because it is a very old-fashioned term. We look for another option, what it should be. (Shipibo TAP: 10 December 2014; translated by the authors) ${ }^{16}$
}

Nonetheless, it could be argued that it is the older generations who would benefit the most from having the Act translated into their mother language, as the younger generations tend to have higher competence in Spanish and more access to information about current affairs, along with the attendant terminology and phraseology. This can be interpreted as a 
reflection of the indigenous language revitalization agenda, which weighs heavily on the minds of the State-qualified indigenous translators. ${ }^{17}$

Although the strategies mentioned above illustrate their willingness to make the Indigenous Languages Act accessible, the most obvious example of how the Ashaninka, Ancash Quechua, Chanka Quechua and Shipibo respondents identified with their peoples is the aforementioned shift in text-producer/text-receiver interaction, which influenced their translational behavior. The Chanka Quechua respondent encapsulates the motivation behind the shift as follows:

\section{The objective was to communicate and get people to appropriate the Act for themselves, that is to say, this is an Act that defends our rights [...]. That is why here the person speaking is a person on the inside, who says "our languages", "ours", so it was a strategic choice too. (Chanka Quechua TAP 2014; translated by the authors) ${ }^{18}$}

The use of the first-person plural removes the State (as "impersonal" sourcetext producer from the target text, where it is replaced by a speaking subject who aligns himself/herself with the text receivers. The Chanka Quechua translation reviser clarified this strategy as far as the translation into that language was concerned (personal communication, email, September 2017). She pointed out, on the one hand, that Quechua necessarily requires the speaking subject to be present in the utterance; this subject, in the case of a legislative Act, is the State. On the other hand, she explained that the use of the inclusive "we" in Quechua ( $\tilde{n} u q a n c h i k)$ rather than the exclusive "we" ( $\tilde{n} u q a y k u)$, positions the State together with all indigenous peoples and refers to all their languages, the word siminchikkuna ("our languages") being in the inclusive plural.

The combination of this strategic behavior with other decisions as to how to relay the content (such as excluding lexical choices that refer to either highland dwellers or Amazonian peoples, depending on the language into which the Act was being translated, as illustrated above under "METONYMY") may make the translated version of the Act read (or sound) as if it was devised for a specific indigenous linguistic community, excluding all others. This would run counter to the State's professed agenda of promoting equality not only between the Spanish-speaking majority and the speakers of indigenous languages, but also among the speakers of all the Peruvian indigenous languages themselves, however large or small their linguistic communities are and regardless of differences in cultural status.

\section{Concluding remarks}

There is no doubt that translation played a crucial role in the colonization of what is now the Republic of Peru, as it did in the case of other colonized territories of the Americas. From the case discussed here, it might be expected that translation of the text of a legislative Act, which, by definition, represents the will of a State that occupies a hegemonic position with regard to its indigenous populations, would contribute to perpetuate that hegemony. In terms of the transmission of ideology that the exercise of hegemony entails, translating the Indigenous Languages Act could arguably be expected to be on a par with translating Christian religious texts, as occurred in earlier times and still occurs in the present day.

However, there are significant contextual factors here that serve to counter such an argument. The Indigenous Languages Act was brought before Congress by indigenous members of parliament and approved in response to demands from their grassroots organisations. The translators in question are indigenous people themselves, working avowedly in favour of their communities of origin. The Indigenous Languages Act is thus a 
manifestation of the will of the contemporary Peruvian State to be seen as upholding and promoting the linguistic and cultural legacy of the autochthonous population of the country. In this respect, this translation initiative can most rightly be seen as countering the abovementioned hegemony, in that it signifies an innovative attempt to translate a piece of State legislation on indigenous rights into the indigenous languages of the country.

In this paper, we have provided an overview of how the communicative interface between the State and the indigenous population is being managed through translation in $21^{\text {st }}$ century Peru, and, more specifically, an insight into how strategic decisions were instantiated in the translations of the Indigenous Languages Act into five Peruvian indigenous languages. The inclusion of two dialectal varieties of Quechua (Ancash and Chanka) contributed to prove that translation choices were not determined by the make-up of the languages in question, as the variation illustrated in the analysis shows.

Based on our evidence, the translators clearly perceived the source text as a piece of legislation that, supportive though it may be of the linguistic human rights of their peoples, relates to a sociocultural sphere that is alien to those that it seeks to protect (Rao 2006). However, the fact that it is enshrined in the national legislation and that, therefore, it is binding for all Peruvian citizens regardless of their ethnic or linguistic background, did not prevent the translators from making it "their own".

It can be argued that the translators" "subversion" of the source text was possible because of the communicative and symbolic, rather than legislative, value of the translations. As the participants in the TAPs related, the target texts became a means to communicate information, to make a piece of legislation accessible and relevant to their peoples (as the Ashaninka, Ancash Quechua, Chanka Quechua and Shipibo translators made clear), or an attempt to reproduce a genre that is alien to the target audience in their own language (as the Aymara respondent asserted).

The lack of equal status between legislation written in Spanish and the translation thereof into the indigenous languages of Peru stands in stark contrast with the situation within national borders elsewhere described by Cao (2007: 103). This can be understood as a manifestation of the asymmetries that characterize intercultural relations in the LatinAmerican context. The fact that to date there is no system in Peru for authenticating translations of legal texts in indigenous languages (which, arguably, made the aforementioned shift in function acceptable) can be seen to be related to the socioeconomic situation in $21^{\text {st }}$-century Peru, a developing country with low levels of education, especially among the indigenous population. An authentication procedure would require the validation of the target texts by a State body that would take the advice of qualified legal experts who have sufficient knowledge of the indigenous languages. These are few and far between, and can cover only a narrow range of languages between them. Additionally, there is at present no official organization in Peru whose remit includes authentication of legal translations into the indigenous languages.

Having said all that, it is noticeable from the TAP respondents' reflections that they were aware of the translation strategies of which they could avail themselves to negotiate the differences between the cognitive structures that characterize their indigenous cultures (Legrand 1996) and those that are immanent (Rao 2006) in the Peruvian rule of law; yet, the major stumbling blocks that they said they had encountered were related to cultural asymmetries between the constructs of the Spanish-speaking State and those of their own peoples. The difficulty in handling the lack of one-to-one lexical equivalents, which is commonplace between any pair of languages, pales in comparison with the difficulty that lies in conveying concepts such as "rights", "heritage" or "private" that are either alien to or conceptualized differently by indigenous communities, as the respondents indicated. 
It could be argued that a limitation of the methodology that we chose is that the findings derived from the data analysis may conflict with those that could be elicited from contrastive text analysis. Yet this potential limitation is offset by the insights into translational behavior that the respondents' reflections afforded us; their perceptions were, after all, our object of analysis. The methodology also highlighted the need to determine how the target texts were perceived by their intended target audiences and whether or not the State-led translation initiative raised awareness of linguistic rights among indigenous communities and, just as importantly, among Spanish speakers. ${ }^{19}$

These are, we believe, important issues that should be considered when reviewing translation policy in the broader context of language policy. The communicative and symbolic value of the translation of the Indigenous Languages Act into the Amerindian languages of Peru needs to be evaluated in the context of the State's objectives of effectively disseminating information to the beneficiaries of the Act and of raising awareness about language rights among the general population and, especially, the providers of public services.

\section{ACKNOWLEDGMENTS}

This article is based on research conducted as part of the project entitled "Translating cultures: the legislated mediation of indigenous rights in Peru", sponsored by the UK's Arts and Humanities Research Council (award AH/M003566/1) under their Translating Cultures theme. We gratefully acknowledge the financial support provided. We are also grateful to the Peruvian Ministry of Culture for providing us with the translated versions of the Indigenous Languages Act and facilitating access to the indigenous translators, and to the NGO Asociación Servicios Educativos Rurales SER), our project partner

\section{NOTES}

1. See Howard, Andrade and de Pedro Ricoy (forthcoming) for an anthropological linguistic analysis of some of the data discussed in this article.

2. The Act was approved during the administration of President Alan García (2006-2011). However, as a change of government came about immediately afterwards, its implementation Fell to the government of President Ollanta Humala (2011-2016).

3. As the Amerindian cultures are primarily oral, and literacy in the indigenous languages is only in its infancy, this is an effective dissemination strategy. The process of commissioning translations of the Languages Act into the indigenous languages has currently been suspended while they review the objectives of the exercise (Ministry of Culture representative, personal communication, email, September 2017).

4. Since Even-Zohar posited in the late 1970s that cultural and linguistic systems are never equally positioned and that power governs the relationship between social groups, a number of Translation Studies scholars have expanded on these points from different perspectives (Callon 1986, Venuti 1995, Tymoczko and Gentzler 2002, Wolf and Fukari 2007).

5. It can be argued that her second scenario does not only apply to monolingual jurisdictions, as Cao (2007) claims: the need to translate legal texts into a foreign language may also arise in a multilingual country. 6. An alternative method of handling the relationship between legal documents and their translations is discussed by Mason (2012 [2003]: 400) who notes, "it is official policy in all EU institutions that translations are not referred to as such but rather as 'language versions', i. e. the different language versions are treated as if they are the original product when they are not; the lack of transparency around translation is an issue in itself." 7. We follow Aníbal Quijano's definition of coloniality, as one of the key elements of global capitalism, which originated in America and became globalised from this continent. According to Quijano (2014: 285), although coloniality is based on racial-ethnic classifications, it permeates every sphere and dimension of daily existence 
in the countries that were subjected to colonial domination. It is to these countries that we refer as 'postcolonial'.

8. The TAPs, designed by de Pedro Ricoy, were conducted by Howard and Andrade, who have good knowledge of Chanka Quechua, Ancash Quechua and Aymara, but not of Ashaninka or Shipibo.

9. The Dirección de Lenguas Indígenas, its name in Spanish, is part of the Viceministry for Intercultural Affairs. 10. No he visto en ninguna otra traducción tomar la palabra "aru" con este sentido, pero conversamos con el profesor X. [...] Aquí hemos tenido que consultar al mismo abogado del Ministerio de Cultura: ¿qué significa eso de "traducción directa e inversa que garanticen..."?

11. Tenemos un traductor que tiene bastante experiencia en este tema de traducir, leer y esas cosas con orientación más comunicacional que transmitir así exactamente como un calco de las cosas, entonces le hicimos una consulta...

12. Para traducir esta Ley hemos consultado a varias personas, para consensuar, por ejemplo, a mi mamá, a mis hermanas, a mis cuñados, primos, que son profesores bilingües. (...) Hemos recibido varios aportes para la traducción, pero finalmente decidimos qué se pone.

13. [...] manejar el lenguaje jurídico es complicado. Es otro lenguaje, ¿no? Entonces, quien tenga que traducir un texto jurídico tiene que entender bien la ley, si no va a ser fatal. Porque esa ley la va a aplicar un abogado, ¿no? Y si el traductor traduce mal un artículo, de otra manera, es como si ya hubiera firmado el Presidente de la República, así que puede valer esa traducción y la culpa no la va a tener finalmente él, ¿no? Y puede, de repente, haber una mala interpretación legal.

14. Hay que tener en cuenta que estábamos haciendo la traducción precisamente para los hablantes; entonces, es un grupo que no necesariamente ha tenido tanta exposición a este tipo de documentos. Como no están familiarizados, entonces [...] la intención era comunicar, más allá de mantener las formas. See Howard, Andrade and de Pedro Ricoy (forthcoming) for additional discussion of this point.

15. The Jesuit priest Ludovico Bertonio's dictionary records thokhriri with the meaning "gouernador de pueblos" [villages' administrator; translated by the authors] (1984 [1612]: 360).

16. Porque las personas ancianas van con términos muy antiguos que ya no es la palabra cotidiana de nosotros, sobre todo los jóvenes. Pueden hablar entre ellos las personas ancianas, pero la juventud ya no habla y por más que puede ser, también lo hemos dejado un rato y no lo ponemos porque es un término muy antiguo. Buscamos otro, qué debe ser.

17. Elsewhere in the TAP interview, the Shipibo respondent asserted that his goal in conducting the translation was not "to revitalise the language". Generally speaking, a purist approach prevails in language revitalisation circles, whereby recourse to neologisms and archaisms is preferred to assimilation of borrowings.

18. El objeto era comunicar y hacer que la gente también se apropie de la Ley, o sea esta es una ley que defiende nuestros derechos (...). Por eso es que aquí la persona que habla es una persona que está adentro, dice "nuestras lenguas," "nuestras," entonces era más estratégico también. See Howard, Andrade and de Pedro Ricoy (forthcoming) for additional discussion of this point.

19. These are aspects of our research that we shall elaborate on in future publications.

\section{REFERENCES}

Austin, John L. (1962): How to do Things with Words. Oxford: Oxford University Press.

BASSnetT, Susan and TRIVEDI, Harish eds. (1999): Postcolonial Translation: Theory and practice. London and New York: Routledge.

BERTONIO, P. Ludovico (1984 [1612]): Vocabvlario de la lengva aymara. Cochabamba: CERES.

BHABHA, Homi (1994): The Location of Culture. London and New York: Routledge.

CALlON, Michel (1986). Some Elements of a Sociology of Translation: Domestication of the Scallops and the Fishermen of St Brieuc Bay. In: John LAW, ed. Power, Action and Belief: A New Sociology of Knowledge. London: Routledge \& Kegan Paul, 196-233.

CAO, Deborah (2007): Translating Law. Clevedon: Multilingual Matters

CORREIA, Renato (2003): Translation of EU legal texts. In: Arturo TOSI, ed. Crossing Barriers and Bridging Cultures: The Challenges of Multilingual Translation for the European Union. Clevedon: Multilingual Matters, 38-44.

Durston, Alan (2007): Pastoral Quechua: The History of Christian Translation in Colonial Peru, 1550-1650. Notre Dame: University of Notre Dame Press

Glanert, Simone (2014): Comparative Law - Engaging Translation. Abingdon and New York: Routledge.

HANKS, William F. (2010): Converting Words: Maya in the Age of the Cross. Berkeley: University of California Press.

Hermans, Theo, ed. (2006): Translating Others Vol. 1. Manchester: St. Jerome.

HERMANS, Theo, ed. (2014): Translating Others Vol. 2. London and New York: Routledge. 
HowARD, Rosaleen, ANDRADE CIUDAD, Luis and DE PEDRO RICOY, Raquel (forthcoming): Translating rights: the Peruvian Languages Act in Quechua and Aymara. Amerindia. Revue d'Ethnolinguistique Amérindienne, 40.

LEgRAND, Pierre (1996): European Legal Systems Are Not Converging. The International and Comparative Law Quarterly, 45(1): 29 p. Visited 1 June 2016, <http://www.pierre-legrand.com/european-legalsystems.pdf>

MASON, Ian (2012 [2003]): Text Parameters in Translation: Transitivity and institutional cultures. In: Lawrence VENUTI, ed. The Translation Studies Reader. New York and London: Routledge, 399-410.

Ministerio De Cultura Del Perú (2011): LEY N 29735. Ley que regula el uso, preservación, desarrollo, recuperación, fomento y difusión de las lenguas originarias del Perú. Ministerio de Cultura del Perú. Visited on 19 September 2016, <http://centroderecursos.cultura.pe/es/registrobibliografico/leyn\%C2\%B0-29735-ley-que-regula-el-uso-preservaci\%C3\%B3n-desarrollo-recuperaci\%C3\%B3n>.

NIRANJANA, Tejaswini (1992): Siting Translation: History, Post-Structuralism, and the Colonial Context. Berkeley, Los Angeles, London: University of California Press.

NorD, Christiane (2005): Text Analysis in Translation: Theory, Methodology, and Didactic Application of a Model for Translation-oriented Text Analysis. Amsterdam and New York: Rodopi.

PITARCH, Pedro (2001): El laberinto de la traducción: la Declaración Universal de los Derechos Humanos en tzeltal. In: Pedro PITARCH, and Julián LÓPEZ GARCÍA, eds. Los derechos humanos en tierras mayas: política, representaciones y moralidad. Madrid: Sociedad Española de Estudios Mayas, 127-160.

QuiJano, Aníbal (2014): Colonialidad del poder y clasificación social. In: Aníbal QuiJANO. Cuestiones y horizontes. De la dependencia histórico-estructural a la colonialidad / descolonialidad del poder. Buenos Aires: CLACSO, 285-327.

RAO, Sathya (2006): From a postcolonial to a non-colonial theory of translation. In: Naoki SAKAI, and Jon Solomon, eds. Translation, Biopolitics, 'Colonial Difference'. Hong Kong: Hong Kong University Press 73-94.

ŠARŠEVIĆ, Susan (1997): New Approach to Legal Translation. The Hague, London, Boston: Kluwer Law International.

SimON, Sherry (1996): Gender in Translation: Cultural identity and the politics of transmission. London and New York: Routledge.

SPIVAK, Gayatri Chakravorti (2012 [1993]): The politics of translation. In: Lawrence VENUTI, ed. The Translation Studies Reader. New York and London: Routledge, 312-330.

TOURY, Gideon (1995): Descriptive Translation Studies and Beyond. Amsterdam and Philadelphia: John Benjamins.

TyMoczKo, Maria and Gentzler, Edwin (2002): Translation and Power. Amherst: University of Massachusetts Press.

VAn Den HaAK, Maaike J., De Jong, Menno D.T. and Schellens, Peter Jan (2003): Retrospective vs. concurrent think-aloud protocols: testing the usability of an online library catalogue. Behaviour \& Information Technology. 22(5): 339-351.

VENUTI, Lawrence (1995): The Translator's Invisibility. London: Routledge.

WOLF, Michaela and FUKARI, Alexandra, eds. (2007): Constructing a Sociology of Translation. Amsterdam and Philadelphia: John Benjamins. 